\title{
The Motives of Television Journalists Participating in the Journalist Competency Test
}

\author{
Moehammad Gafar Yoedtadi ${ }^{*}$ Gregorius Genep Sukendro $^{1}$ Lusia Savitri ${ }^{1}$
}

\author{
${ }^{1}$ Faculty of Communication Science, Universitas Tarumanagara, Jakarta 11440, Indonesia \\ *Corresponding author.Email: gafary@fikom.untar.ac.id
}

\begin{abstract}
Journalist certification is a program of the Press Council to improve the competence and professionalism of journalists. The program, which has been running for ten years, is not running smoothly. Of the 40 thousand journalists registered in the Press Council, only 17 thousand have participated in the journalist competency test. The Indonesian Television Journalists Association, a journalist organization under the Press Council, from 1863 its members were only able to test 745 journalists. The reason is that journalist certification does not linearly affect journalists' welfare. The media where journalists work does not require passing journalist certification. This study aims to explore the motives of television journalists following the journalist competency test using the theoretical basis of Alfred Schutz's motives. Television journalists were selected as samples who had participated in the journalist competency test held by the Indonesian Television Journalists Association. The selection of participants was carried out using a purposive sampling technique, namely television journalists who had participated in the competency test and were members of the Indonesian Television Journalists Association. This study used a qualitative approach with phenomenological methods. The results showed that the because-motives of participating in UKJ were self-proof and pride in being a journalist. Meanwhile, in-order-to-motives is to get public recognition and is different from "abal-abal" (low quality) journalists.
\end{abstract}

Keywords: Motive, journalist competency test, TV journalist

\section{INTRODUCTION}

It has been a decade since February 2, 2010, the Press Council issued a decision on Journalists Competency Standards. The Press Council has compiled a journalist certification level which aims to increase the capacity of the media and the quality of journalists. All journalists who are members of the Press Council are expected to undergo a certification process in the form of a journalist competency test so that they can obtain certification for journalists in stages, young journalists, intermediate journalists, and main journalists [1]. The expected benefit from certification is that the quality of journalists will increase and it will support media capacity and media reputation. Journalist competency testing is an important thing that journalists must have as the legitimacy of competence and improving the quality and professionalism of journalists. Certification is no longer just a formality but plays an important role in forming professional journalists [2].

The reason for holding journalist certification by the Press Council is based on the desire to organize a healthy press life. This arrangement is considered important to provide quality assurance to achieve professionalism and media capacity that can compete at the national and global levels [3]. As mandated by Law No. 40 of 1999 concerning the Press, that the Press Council conducts arrangements relating to press organizations and companies, journalists 'organizations, and journalists' competence [3]. Since the Press Council stipulates that journalists must have certification, some media, journalist organizations have begun to organize and align activities with the journalist certification process. One of the journalist professional organizations that have been assigned as a journalist testing institution is the Indonesian Television Journalists Association (IJTI).

Journalists who are serious about their profession welcome the Press Council decision because they realize that good journalists are those who always try to improve themselves, increase their knowledge, broaden their horizons. In carrying out his profession, a journalist must have adequate competency standards and is agreed upon by the press community. Competency standards are a measuring tool for journalist professionalism in protecting public interests and private rights of society, as well as maintaining the honor of the journalist profession [4].

Basically, the journalist profession cannot be equated with other types of professions, such as the legal and medical 
professions because they appear more autonomous in carrying out their duties. In the journalist profession, various aspects are bound, including ethics, law, professionalism, and technical skills. The advancement of mass communication technology requires journalists to continuously develop in terms of insight and intellectuality.

Journalists have a role and duty to convey messages to the public. The strategic position of journalists can determine public opinion. The journalist's strategic position must be carried out wisely and carefully. Apart from that, it requires professionalism [5].

The Press Council's efforts to encourage the improvement of journalists' technical skills and insights by making the journalist certification program do not run easily. Of the 40 thousand journalists registered in the Press Council, only 17 thousand have participated in the journalist competency test. The Indonesian Television Journalists Association (IJTI), one of the journalists' organizations under the Press Council, for example, out of 1863 members, only 745 journalists were able to test. The reason is that journalist certification does not linearly affect the welfare and career advancement of journalists. Meanwhile, many media where journalists work do not require passing journalist certification to work in their media [4]. So what is their motivation to take the journalist competency test? This research intends to see and explore the motives of television journalists who have participated in the journalist competence test held by IJTI.

This study uses the phenomenological theory of Alfred Schutz which understands individual social action through interpretation. Social action is an action-oriented towards the behaviour of people or other people in the past, present, and future. To describe the overall actions of a person, Schutz grouped them into 2 phases, namely:

1. Because-motives are actions that refer to the past. Where the action that will be done by someone must have reasons from the past when he did it and;

2. In-order-to-motive, which is a motive that refers to future actions. Where the actions taken by someone must have a predetermined goal. This study intends to look at the motives of the because and the motives of a journalist's goals in following the journalist competency test [6].

Based on the above background, this research has a problem formulation, what are the motives of television journalists in following the journalists' competency test?

\section{BACKGROUND}

\subsection{Literature Review}

Before this research, there had been several studies that examined journalists' competency tests. The first is a study entitled Review of Journalists' Competency Standards to Increase Media Capacity and Professionalism. The research conducted by D. Waluyo (2018) has been published in the Journal of Communication and Media volume 22 No.2 [4]. The research aims to review the competence certification of journalists by taking competency benchmarks based on the decisions of the Press Council, namely awareness, knowledge, and skills (skills). This research uses a qualitative approach with a case study method. Data mining was carried out by indepth interviews with informants, namely journalists of the Tempo Weekly News Magazine, lecturers at the National University of the Faculty of Letters and Culture in the Media Studies Sector, journalists for the Warta Kota newspaper, journalists for Trans TV media, members of the Press Council, and journalists for the Jakarta Mystery magazine. The results of the study concluded that there was no media commitment to obliging journalists to take journalist competency certification. The difficulty in achieving professional standards is due to the lack of awareness of being a journalist. Another official factor is the salary standard for journalists, which is still low and varies in various media, making journalistic work not optimal.

The second research is the research of Wijaya and Ruthinia entitled Increasing National Intelligence through Optimizing the Application of Journalist Competency Standards. This research has been published in the Journal of Communication of the Indonesian Bachelor of Communication Association vol 1 no 2 of 2016 [7]. The research uses a qualitative approach with an emphasis on literature studies as an effort to extract data. The purpose of this research is to examine the optimization of the results of journalist competency standards carried out by the Press Council. The results of the study conclude that optimizing the application of journalist competency standards in Indonesia can at least be achieved through (1) optimizing training / courses / workshops / comparative studies, (2) optimizing monitoring and evaluation, (3) optimizing awarding, (4) ) optimizing the application of sanctions in an objective, selective, gradual, fair, procedural, and educational manner, (5) optimizing journalists 'welfare, (6) optimizing journalists' advocacy, (7) optimizing journalist competency tests.

The third research that examines journalist competency standards is a study entitled Implications of Competency Test on Legal Awareness of Print Media Journalists in Denpasar. It is Adnyana's research and has been published in the Journal of Magister Hukum Udayana volume 4 no 2 of 2015 [8]. This study aims to examine the implications of competency testing on the legal awareness of print media journalists in Denpasar. The study in this research concerns people's behaviour towards the law, therefore it is classified as a sociological legal study (socio-legal research). Law as an empirical social phenomenon is studied as an independent variable or because of that causes influence and effect on various aspects of life social. To obtain data on the implications of the competency test on the legal awareness of print media journalists in the city of Denpasar, the statute approach and the legal concept approach as applicable in people's lives were used. The results of this study concluded that the journalist competency test had not been specifically regulated in press law. The implementation of the journalist competency test is only regulated based on Press Council Regulation Number 1 / Regulation-Dp / II / 2010 
concerning Journalist Competency Standards, as one of the manifestations of the Press Council's function in conducting studies for the development of press life as well as establishing and overseeing the implementation of the Journalistic Code of Ethics. In general, the implementation of the competency test has implications for the legal awareness of print media journalists in the city of Denpasar. The competency factor also affects journalists' legal awareness of press law.

The fourth study is entitled 'Competency Test Analysis for PWI East Java Journalists to Improve Professionalism. The research was conducted by Suhermono and Paremo and aims to analyze the efforts of PWI East Java to improve the professionalism of its members through journalist competency tests. This research uses a descriptive qualitative approach with the case study method, which has been published in the Journal of Media Studies vol 1 no 2 of 2017 [9]. The results of the study conclude that there is a correlation between journalists who have taken journalists' competency tests and their professional attitudes in carrying out their work. Although in its implementation there must be continuous improvement and evaluation so that the results are of higher quality. At a minimum, the journalist competency test can be a kind of "brake" for journalists so as not to violate the journalistic code of ethics. This is evident in the past 5 years, PWI East Java has received less and fewer complaints from the public regarding alleged violations committed by its members.

The fifth research is R. Trisnayanti's research entitled The Professionalism Analysis of Beritagar.id Journalists in the Post Truth Era [10]. The research, which has been published in the Journal of Communication Science vol 2 no 3 of 2019, uses a qualitative approach to the phenomenological method to explore the professional experience of Beritagar.id journalists so that this experience contributes to professionalism in the post-truth era. The results showed that: (1) Beritagar.id becomes a forum for experienced journalists to apply their skills. Beritagar.id journalists have strong relationships. They are skilled at writing interpretive news, journalistic discipline in uncovering the truth, balanced in shaping public opinion, utilizing social media as a source of supporting news and data journalism (2) the values of journalistic code of ethics are applied by Beritagar journalists makes Beritagar.id journalists have integrity, independence, and their dignity and professionalism are maintained (3) the special knowledge of Beritagar.id journalists is actualized as they work, so they are not negligent of new phenomena, namely post-truth (4) Journalist Competency Test and certification for journalists Beritagar.id is not fully a benchmark for journalist professionalism.

From previous studies, it can be said that this research has a difference and novelty. First, the research subjects are focus on television journalists. Second, the object of this research is the television journalist's motive in following the journalistic competency test.

\subsection{Journalist Professionalism}

Formulating journalist competence is something that has never been agreed upon. Stefan Russ-Mohl, a German scholar, once wrote that determining quality in journalism is very similar to the attempt "to nail the pudding to the wall" [11]. However, a German scholar Siegfried Weischenberg introduced a schematic model of competence in journalism which consists of five factors.

1. Professional Competence. Included in this competency are having basic skills and professional knowledge in mass communication, including media effects and research in the field of journalism that contributes to theory.

2. Transfer Competence. The ability to convey mass media messages to the audience/readers.

3. Technical Competence. Covers basic computer skills as well as the use of the internet and electronic databases. Apart from these general skills, journalists also need specific competencies such as in the field of publishing and mastery of tools.

4. Expertise Competence. Failures in journalism are often caused by a lack of knowledge about the subject. Therefore, a journalist's background knowledge is very important. For example, a journalist who specializes in covering the economy must always follow the ongoing economic developments. Likewise, journalists who specifically cover scientific matters must have a qualified background in scientific knowledge.

5. Social Orientation. It encompasses an awareness of the function and autonomy of journalists in the mass media system as well as their ability to reflect and criticize alarming developments in their own profession. But "orientation" does not mean "control", but is meant as "guiding". In this category, journalists are required to understand the awareness of work ethics and dare to criticize the work system if it is considered quite contrary to journalistic idealism. This needs to be done because within the scope of a journalist's work there are many interests such as owners of capital, government, sources, advertisers, and others. It is hoped that the news produced by journalists remains fair and does not take sides with any party.

The Press Council, in Regulation Number 1 / Regulation DP / II / 2010, defines journalist competence as the journalist's ability to carry out journalistic activities that demonstrate knowledge and responsibility according to the required professionalism. Journalists 'competency standards are aimed at: (1) Improving the quality and professionalism of journalists, (2) Becoming a reference system for evaluating journalists' performance by press companies, (3) Upholding press freedom based on public interest, (4) Maintaining the dignity and dignity of journalists as a special producing profession. intellectual works, (5) Avoiding abuse of the journalist profession, (6) Placing journalists in strategic positions in the press industry [3]. 
Based on the formulation of the Press Council, there are at least three categories of competency formulations that a journalist must have, namely [3]:

1. Awareness: including awareness of ethics, law, and career paths.

2. Knowledge: includes general knowledge and specific knowledge according to the journalism field concerned.

3. Skills: includes writing skills, interviews, research, investigation, using various equipment, such as computers, cameras, editing equipment.

\subsection{Motive in Alfred Schutz's Theory of Phenomenology}

One of the research methods contained in social science is phenomenology. Phenomenology is generally known as a research method used to help understand various social symptoms or phenomena in society. The main purpose of phenomenology is to study how phenomena are experienced in consciousness, thought, and inaction, such as how the phenomenon is valued or accepted aesthetically. Phenomenology tries to find an understanding of how humans construct important meanings and concepts within the framework of intersubjectivity. Intersubjective because our understanding of the world is shaped by our relationships with other people. Although the meanings we create can be traced in the actions, works, and activities that we do, there are still roles for other people in it [6].

One of the social scientists who are competent in paying attention to the development of phenomenology is Alfred Schutz. He linked the phenomenological approach to social science. Apart from Schutz, actually social scientists who pay attention to the development of phenomenology are quite a lot, but Schutz is one of the pioneers of the phenomenological approach as an analytical tool in capturing all the phenomena that occur in this world. Besides, Schutz compiled a phenomenological approach in a more systematic, comprehensive, and practical way as an approach that is useful for capturing various phenomena in the social world [12].

The essence of Schutz's thought is how to understand social action through interpretation, where social action is an action-oriented behaviour of people or other people in the past, present, and future. To describe the overall actions of a person, Schutz grouped them into 2 phases, namely:

1. Because-motives are actions that refer to the past. Where the action that will be done by someone must have reasons from the past when he did it and;

2. In-order-to-motive, namely motives that refer to future actions. Where the actions taken by someone must have a predetermined goal [6].

The motive put forward by Schutz has the basis of Weber's thinking about social action [12]. According to Max Weber, social action is an individual action as long as the action has a meaning or subjective meaning for himself and is directed to the actions of others [13]. This theory helps us in understanding the behavior of each individual or group that each has different motives and goals for an action taken. By understanding the behavior of each individual or group, we can appreciate and understand their reasons for taking action [14].

Based on motive theory, this study aims to answer the journalist motives participating in the journalist competency test.

\subsection{Method}

This paper uses a qualitative approach with a phenomenological method. The qualitative method according to Bogdan and Taylor [15] is a research procedure that produces descriptive data in the form of written or spoken words from people and observable behaviour.

According to Creswell [16], there are several reasons why someone does qualitative research, including:

a. Choosing a qualitative study because of the nature of the research question. In qualitative studies, research questions often begin with how or what.

b. Choose a qualitative study because the topic needs to be explored.

c. Using qualitative studies because it is necessary to present a detailed view on the topic.

d. Choose a qualitative approach because there are sufficient time and resources to use for extensive field data collection and detailed data analysis of textual information.

This study chooses a qualitative approach following the formulation of the problem, namely answering the question of what motives are television journalists following the journalist competency test. A qualitative approach is also used to explore detailed views on the motives of journalists in following the journalist competency test.

Meanwhile, the phenomenological approach, according to Creswell [16], is used by researchers to find the experiences of actors in dealing with their environment. Husserl and Merleau-Ponty explain that phenomenology is used by researchers to reveal the types of experiences, in the form of descriptions, in the past [17].

The phenomenology used in this study is based on Alfred Schutz's perspective. According to Schutz, phenomenology is how to understand social action through interpretation. Social action is an action-oriented towards the behaviour of people or other people in the past, present, and future. Schutz says all human beings carry within themselves the rules, types of behavior, concepts, values that help them behave naturally in a social world. Schutz distinguishes two types of motives, namely inorder-to-motive (which refers to the future) and becausemotive (which refers to the past) [18].

Phenomenology in this study is used to get the motives of television journalists on journalists' competency tests. 
The object of this research is the motives of television journalists to participate in the journalist competency test. The subjects of this study were IJTI member television journalists who had taken the journalist competency test. The informants were three television journalists in Aceh, namely Dicki Juanda (Metro TV), Mustajab (Kompas TV), Hasbi Ibrahim (TVRI Banda Aceh). Interviews were conducted using the telephone because face-to-face meetings were not possible during the Covid-19 pandemic.

\subsection{Results}

\subsubsection{Findings}

Journalist certification is a program of the Press Council to improve the competence and professionalism of journalists. The program, which has been running for ten years, is not running smoothly. Of the 40 thousand journalists registered at the Press Council, only 17 thousand have participated in the journalist competency test. The Indonesian Television Journalists Association, one of the journalist organizations under the Press Council, for example, out of 1863 members, only 745 journalists were able to test. The reason is that journalist certification does not directly affect the welfare of journalists. Also, the media where journalists work does not require passing journalist certification. However, for journalists who are members of IJTI there is still enthusiasm for participating in UKJ, with various motives as reasons. According to Weber, these subjective meanings and motives are directly related to human action [19]. An important motive in seeing the reasons for the participation of television journalists in participating in UKJ. Motive can be seen as because-motive, and in-order-to-motive.

\subsubsection{Because-motive}

Because-motive is related to someone's reason for taking an action in an attempt to create expected situations and conditions in the future. In other words, because-motive is what makes a person perform certain actions. In this study, there were various kinds of informants' motives for participating in the journalist competency test. These motives include self-proof and pride to be a journalist

\subsection{Self-proof}

In general, the informants are contributors to television stations based in Jakarta, namely Kompas TV, Metro TV, and TVRI. The contributor status is a freelance journalist and not a permanent employee. Having that status certainly does not have certainty in career paths and increased welfare. As a contributor, they are only bound by a news broadcast contract or a so-called partner contract which is renewed once a year. Thus, even if they take the journalist competency test, it is more motivated by the desire to prove their own competence.
The informant's background as a member of a professional organization, the Indonesian Television Journalists Association (IJTI), is the background for participating in the journalist competency test. The obligation to reach the level of competence becomes the basis for IJTI members to take part in UKJ. The informants who are members of IJTI admit that they have the responsibility to reach the competency stage and this has been proven in the UKJ event. Those who are members of the IJTI in the Aceh regions do not want to be left behind to get a UKJ pass mark when regional IJTI administrators in collaboration with the Central IJTI hold a UKJ.

The motive for proving self-competence is the strongest impetus to join UKJ. Competence, both in terms of journalistic knowledge and skills, requires verification through UKJ. According to the informants they have often received training from the office where they work. Beside knowledge of the journalistic code of ethics has been studied as a handbook of daily work.

"I have been working as a journalist for a long time, it needs to be proven whether we are truly competent, so we join UKJ. Actually, we have done what we have been tested before, it is a work every day, only if we are tested it is appropriate, if we pass it means we are competent. (20)

"So all this time we have worked according to the initial training we have attended, namely journalism training, whether it be television journalism or radio journalism. But then it is necessary to get or be recognized that we are indeed considered as journalists who work according to professional rules, it is recognized as having the ability that we say is in accordance with the basic point of view of our work in the media, which seems to us that apart from knowing our potential, to what extent we are able. and not too grandiose if we must be recognized professionally." [21]

"I have participated in general education and training at the central TVRI in Jakarta, apart from training for mojo, mobile journalism from TVRI. The materials tested already know us. We work based on TOR, so we follow TOR's requests, what is asked, how to make good news. " [22]

\subsection{Proud to be a journalist}

All informants said they were proud to be journalists. Although they have a relatively small income, the journalist profession has a big social responsibility. Journalists, according to them, are mediators between the people and the government. People can convey their aspirations through journalists, on the other hand, the government can find out what the public wants through the media. Also journalists are obliged to ward off various disinformations (hoaxes) that have recently been circulating.

"The contributor's salary is small, but the inner satisfaction is big. We are the connector of the people's aspirations, as social control, helping the advocacy of the people who are struggling. I once helped children in the correctional institution (prison) to be able to take exams, I feel very 
satisfied. Apart from that, journalists straighten out confusing news, especially hoaxes. " [20]

"Yes sir, if the basis of my conscience is that we see a lot of gaps, we say it is far from mediocre, we see many things that are not clear, sir. With the role of journalism, for example, at least $50 \%$ or $30 \%$ can control this social situation. That is, in my opinion, bang. [22]

\subsubsection{In-order-to-motive}

In-order-to-motive is a retrospective view of the factors that cause a person to take certain actions. In other words, in-order-to-motive is a goal to be achieved by someone who performs a certain action. In short, in-order-to-motive is the goal that the informants want to achieve by taking the journalist competency test, which is to get recognition from the public and differentiate it from "abal-abal" (low quality) journalists.

\subsection{Get recognition from the public}

The desire to get recognition from the public as a competent journalist following the rules and requirements of the Press Council seems to be the main driving force in taking the journalist competency test. This emerged from interviews conducted by researchers with informants. Recognition as a competent journalist can be an asset when dealing with sources in particular and society in general. At the same time, a sign of competence will increase the confidence of the source in them.

"So that we are recognized in front of the source as professional journalists. Some sources like to ask, are we journalists right or not, bypassing the UKJ we have a card from the Press Council, obviously there is recognition from an official institution, we are journalists. Sources will also believe in us. " [20].

Informant 2 admitted that he often received questions from news sources regarding journalist competence. As Secretary General of the IJTI Aceh region, informant 2 must explain the source's right to refuse an interview request if the journalist has not passed the UKJ.

"Indeed, there are many sources, for example, when we chat, exchange opinions, if, for example, this is conveyed by a source, bro, if for example there is a media that wants to interview me, I have the right to ask that journalist has taken the competency test as a journalist and declares that he is not competent. This means that I have the right as a resource to refuse interviews of journalists who do not or have not attended the UKW (Journalist Competency Test) and have not been declared competent to work as a journalist. This means that these things provoke us to participate. The results of UKW are proof as journalists that we do follow that competence, one of which is that we are recognized by the Press Council as competent young journalists.” [22]

\subsection{Distinguishing from "abal-abal" (low quality) journalists}

Informant 2 and informant 3 said that currently in their coverage area a lot of media and journalists work unprofessionally. The media and journalists who are often categorized as "abal-abal” (low quality) are considered not having adequate journalistic skills. This disturbs the public and journalists who are professional. In order to differentiate it from these "abal-abal" journalists, the informant intends to attend UKJ.

"UKJ is important for us because it shows which journalists

are professional and which are 'abal-abal'. There are many unclear media and journalists circulating in Pidie, they are just looking for sensations. His journalistic skills are also absent. Never mind writing news scripts, you can't even write text messages. So that foundation is why I joined, I was able. By joining the UKJ, our position is clear, there is recognition from official institutions that we are professional. " [21]

"For example, when interviewing sources, in the midst of an outbreak like this, the source should still wear a mask, but they instead ordered to remove the mask on the grounds that the mask interfered with the sound of the interview, even though if it was seen on television not wearing a mask was the same as teaching the wrong thing. Or there is more laziness they cover, sometimes arriving late, then begging for pictures, honestly there are still, don't come, come late, don't want to work, just take it.” [22]

\subsubsection{Discussion}

\subsubsection{Because-motive}

Because-motive following UKJ, namely self-proof and pride as a journalist can be explained in two ways. First, journalists realize that the professional responsibilities they carry out have the domain of three justifications of expertise, duty, and autonomy [23]. Expertise is defined as the domain of specialists, often technical or formal knowledge. The informants realized they had the expertise and knowledge practiced in daily journalistic work. For that, they want to show or prove that they are competent. Then, duty is the concept that profession is 'more than just job', namely that professionals have broader social obligations than just obeying orders from their employers [23]. Informants are aware that their social role is very large. More than just making news. Autonomy is meant as a level of self-governance in the professional environment, and the extent to which the journalist profession is independent from external influences [23]. The informants who are members of the professional organization IJTI feel they have the autonomy to regulate their own profession based on the journalistic code of ethics.

The motive for being proud as a journalist can also be explained that the informants realized that the profession they carried out was to bring the public's trust to convey 
the correct information. Kovach and Rosentiel [24] in nine elements of journalism emphasize that journalism's first loyalty is to citizens or the general public. Journalism serves the public interest, not serving the interests of a particular group, group of people, or political power.

Referring to the concept of journalist competence from Siegfried Weischenberg which divides competence into Professional Competence, Transfer Competence, Technical Competence, Expertise Competence, Social Orientation [11]. Proud to be a journalist belonging to the category of social orientation, namely social-oriented professional competencies.

\subsubsection{In-order-to-motive}

In-order-to-motive to get recognition from the public cannot be separated from the existence of the press in the community. Sociologically, a journalist is a citizen of the community where he is. They live and carry out journalistic activities in the wider community, as well as become part of the community itself. The press and journalists cannot live and develop alone without the support of the community in which they are located. Both are in a position of mutual need, mutual respect, and understanding [23]. The concept of this relationship gave birth to the theory of social responsibility of the press.

McQuail [25] states that social responsibility requires the press to have a responsibility towards society and must gain the trust of the community. The existence and functioning of a profession require the main prerequisite in the form of public trust in that profession. Without the trust of the community, a profession will not be able to function properly [23]. Public trust that the existence of a journalist profession is indeed useful for living together.

The public trust is shown by journalists with competence. Nurudin [5] explains journalist competence is an absolute must because journalists' work is closely related to the intellectual progress of society. A smart society is formed because it has a smart press.

Meanwhile, in-order-to-motive as not to be confused with "abal-abal" journalists, is a self-concept construction that is owned by the informants. The self-concept according to Blumer is a person's overall perception of himself and his environment which is formed from the results of his interpretation when interacting with others [26]. Selfconcept is a perception of oneself, whether physical, social, or psychological, which is based on experiences resulting from interactions with other people. An individual will build a self-concept by interacting with the environment, then this self-concept will provide important motivation for behaviour.

The self-concept of the informants, namely professional journalists, is formed from the results of construction and interpretation of "abal-abal" journalists in society. The presence of "abal-abal" journalists got a negative perception from the public. "Abal-abal” journalists work without heeding the code of ethics. It is often unsettling for the public because the news is not of high quality and the method of reporting it often violates ethics. Informants do not want to be confused with "abal-abal" journalists because it would undermine their profession. This is in line with Siregar's [27] thinking that every journalist needs to appreciate the dignity of his profession, as well as himself. This respect for profession and self starts from two things. First, standard skills and qualifications (competence). Second, work ethic orientation in carrying out press duties. The informants realized that they did not want the glory of the profession to be tainted by the dishonorable practices of "abal-abal" journalists. Because of that, they show competence and a good work ethic. The motives of TV journalists participating in the Journalist Competency Test can be described in the following model.

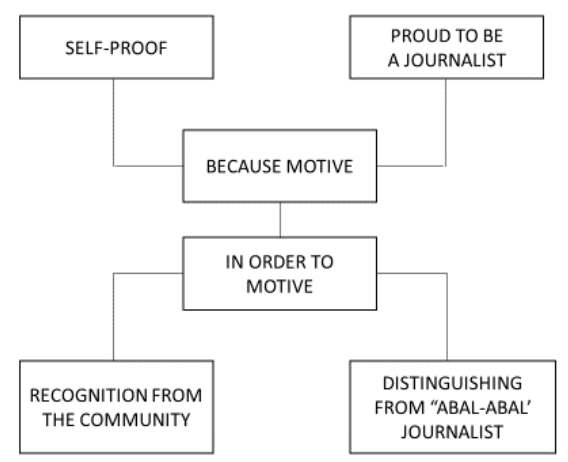

Figure 1 The Model of TV Journalist Motive Partisipating in Journalist Competency Test

\section{CONCLUSION}

Passing UKJ does not immediately improve journalist welfare. Beside the media in which they work generally do not require UKJ. However, journalists are eager to participate in UKJ because they have motives. Becausemotive is self-proof and pride as a journalist. Journalists feel they have journalistic skills from the training they get in the media where they work. Besides they have been working in the journalist profession for a long time to provide them with a long experience. UKJ is a means of proving themselves whether they are competent or not. The sense of pride in being a journalist is also a reason for joining UKJ. A journalist is considered a profession that serves the community more than just making news. Meanwhile, in-order-to-motive is to get recognition from the public and differentiate it from "abal-abal” journalists. Journalists who take part in UKJ have a desire to get recognition as professional journalists from the public and news sources. Bypassing the UKJ they won the trust of news sources. Another in-order-to-motive is to want to be 
distinguished from "abal-abal" journalists who mostly operate in their coverage areas. "Abal-abal" journalists are very disturbing to the public and professional journalists. They want to show that they are not in the same class as "abal-abal” journalists.

\section{ACKNOWLEDGMENT}

This research was funded by Research and Community Service Institute (LPPM) Universitas Tarumanagara.

\section{REFERENCES}

[1] I Made Adnyana. Implikasi Uji Kompetensi Terhadap Kesadaran Hukum Pers Wartawan Media Cetak di Kota Denpasar. Jurnal Magister Hukum Udayana, Vo. 4 No. 2, 2015, pp. 219-232

[2] M. Suhermono, S.A. Pareno. Analisis Uji Kompetensi Wartawan PWI Jawa Timur Untuk Meningkatkan Profesionalitas. Jurnal Kajian Media, Vol. 1 No. 2, 2017, pp. 132-156

[3] L. Luwarso, G. Gayatri. Kompetensi Wartawan Pedoman Peningkatan Profesionalisme dan Kinerja Pers. Dewan Pers, Jakarta, 2006

[4] D. Waluyo. Tinjauan Standar Kompetensi Wartawan Untuk Meningkatkan Kapasitas Media dan Profesionalisme. Jurnal Studi Komunikasi dan Media, Vol. 22 No. 2, 2018, pp. 167 - 184

[5] Nurudin. Jurnalisme Masa Kini. Raja Grafindo Persada, Jakarta. 2009

[6] S. Wulandari. (2016). Motif dan Makna Diri Pria Penata Rias di Kota Pekanbaru Dalam Perspektif Fenomenologi. JOM FISIP Vol. 3 No. 2, 2016, pp. 1-14

[7] S.H.B. Wijaya and F.R. Yudiningrum. Meningkatkan Kecerdasan Bangsa Melalui Optimalisasi Penerapan Standar Kompetensi Wartawan. Jurnal Komunikasi ISKI, Vol. 1 No. 2, 2016, pp. 97101

[8] I.M. Adnyana. Implikasi Uji Kompetensi Wartawan Terhadap Kesadaran Hukum Pers Wartawan Media Cetak di Kota Denpasar. Jurnal Magister Hukum Udayana, Vol. 4, No. 2, 2015, pp. 219-232

[9] M. Suhermono and S. A. Pareno. Analisis Uji Kompetensi Wartawan Jawa Timur Untuk
Meningkatkan Profesionalitas. Jurnal Kajian Media, Vol. 1, No. 2, 2017, pp. 132-156

[10] R. Trisnayanti and D. H. Suwarto. (2019). Analisis Profesionalisme Beritagar.Id di Era Posth Truth. Jurnal Komunikasi, Vol. 2, No. 3, 2019, pp. 52-60

[11] T. Hanitzsch. Rethinking Journalism Educationing Indonesia: Nine Theses. Jurnal Mediator. Vol. 2 No. 1, 2001, pp. 93-100.

[12] S. Nindito. Fenomenologi Alfred Schutz: Studi tentang Konstruksi Makna dan Realitas dalam Ilmu Sosial. Jurnal Ilmu Komunikasi Vol. 2 No.1, 2005, pp. 79-94

[13] A. Pujianti. Tindakan Sosial Tokoh Sentral Anak dalam Novel Tiga Bianglala Karya Misna Mika: Kajian Sosiologi Max Weber. Jurnal Sapala, Vol. 5, No. 1, 2018, pp: 432-448

[14] A. Muhlis and Norkholis. Analisis Tindakan Sosial Max Weber dalam Tradisi Pembacaan Kitab Mukhtashar Al-Bukhari. Jurnal Living Hadis, Vol. 1, No. 2, 2016, pp: 242-258

[15] L. Moleong. Metode Penelitian Kualitatif. Remaja Rosda Karya. 2000

[16] J. W. Creswell. Qualitative Inquiry and Research Design: Choosing Among Five Approaches (2nd ed.). Sage Publication, Inc, California. 2007

[17] A. Hamzah. Metode Penelitian Fenomenologi, Kajian Filsafat dan Ilmu Pengetahuan. Literasi Nusantara, Batu. 2020

[18] Y. F. Aufa and Farid Pribadi. (2017). Motif Memilih Sekolah Islam Di Surabaya. Jurnal Paradigma Vol. 2 No. 2, 2017, pp: 32-40

[19] A. L. K. Sulaiman. (2014). Jurnalis Perempuan: Studi Motivasi Perempuan Memilih Jurnalis Media Massa di Kota Ambon. Jurnal Mediasi, Vol. 8, No. 1, 2014, pp: 35-52

[20] Interview with Informan 1

[21] Interviews with Informan 2

[22] Interview with Informan 3

[23] Z. Nasution. Etika Jurnalisme Prinsip-prinsip Dasar. Jakarta: RajaGrafindo Persada, 2015

[24] B. Kovach and T. Rosentiel. Sebilan Elemen Jurnalisme. Jakarta: Pantau, 2001 
[25] D. McQuail. Teori Komunikasi Massa. Jakarta: Salemba Humanika, 2011

[26] Y. Yuniati, A. Yuningsih, Nurahmawati. (2015). Konsep Diri Remaja dalam Komunikasi Sosial melalui Smartphone. Jurnal Mimbar Vol. 31, No. 2, 2015, pp: 439-450

[27] A. Siregar. Pemberitaan Media Pers Indonesia: Paradigma, Epistimologi, Ruang Publik dan Pendekatan Multikultural. Jurnal Ilmu Sosial dan Ilmu Politik Vol. 9, No. 3, 2006, pp: 255-270. 